Instructions for authors, subscriptions and further details:

\title{
Cultural Capital and Educational Expectations of Native and Immigrant Parents of Primary School Students: Qualitative Study
}

Gerasimos S. Koustourakis $^{1}$

Anna Asimaki ${ }^{1}$

Georgia Spiliopoulou ${ }^{1}$

1) University of Patras, Greece

Date of publication: October $25^{\text {th }}, 2016$

Edition period: October 2016-February 2017

To cite this article: Koustourakis, G., Asimaki, A., Spiliopoulou, G. (2016). Cultural Capital and Educational Expectations of Native and Immigrant Parents of Primary School Students: Qualitative Study. International Journal of Sociology of Education, 5(3), 166-189. doi: 10.17583/rise.2016.1892

To link this article: http://dx.doi.org/10.17583/rise.2016.1892

PLEASE SCROLL DOWN FOR ARTICLE

The terms and conditions of use are related to the Open Journal System and to Creative Commons Attribution License (CC-BY) 


\section{Cultural Capital and Educational Expectations of Native and Immigrant Parents of Primary School Students: Qualitative Study}

Gerasimos S. Koustourakis Anna Asimaki

University of Patras

University of Patras

Georgia Spiliopoulou

University of Patras

(Received: 16 January 2016; Accepted: 18 April 2016; Published: 25

October 2016)

\section{Abstract}

This paper uses the concept of 'cultural capital' from the theory of Pierre Bourdieu and it aims on the one hand to investigate the similarities and differences between the institutionalized and objectified cultural capital of native and immigrant parents of state primary school students in Greece and on the other hand to correlate these two forms of cultural capital with their expectations for the educational future of their children. The research was conducted during the spring semester of 2014 with the use of semi-structured interviews, in which 20 parents (10 native and 10 immigrant) of children in the 6th grade of primary schools in the city of Patras participated. The results of this study showed that there were more differences than similarities between these two categories of parents and they are mainly focused on cultural goods which exist in their house as well as on cultural activities of family members during their spare time. The educational expectations of the sum total of parents of students regardless of national origin and educational level seem to be very high. It also emerged that educational level and occupation of parents is correlated to their specific expectations for the educational future of their children..

Keywords: institutionalized cultural capital; objectified cultural capital; educational expectations; primary school; natives; immigrants 


\section{El Capital Cultural y las Expectativas Educativas de los Padres Nativos e Inmigrantes de los Estudiantes de Primaria: Un Estudio Cualitativo}

Gerasimos S. Koustourakis Anna Asimaki

University of Patras

University of Patras
Georgia Spiliopoulou

University of Patras

(Recibido: 16 Enero 2016; Aceptado: 18 Abril 2016; Publicado: 25

Octubre 2016)

\section{Resumen}

En este trabajo se utiliza el concepto de "capital cultural" de la teoría de Pierre Bourdieu y su objetivo es, por un lado para investigar las similitudes y diferencias entre el capital cultural institucionalizado y objetivado de padres nativos e inmigrantes de estudiantes de la escuela primaria estatal en Grecia y en por otro lado para correlacionar estas dos formas de capital cultural con sus expectativas para el futuro educativo de sus hijos. La investigación se realizó con el uso de entrevistas semi-estructuradas, en las que participaron 20 padres (10 nativas y 10 inmigrantes) de los niños del sexto grado de las escuelas primarias en la ciudad de Patras. Los resultados de este estudio mostraron que había más diferencias que similitudes entre estas dos categorías de los padres y que se centran principalmente en los bienes culturales que existen en su casa, así como en las actividades culturales de los miembros de la familia durante su tiempo libre. Las expectativas educativas de la suma total de los padres de los alumnos, independientemente de su origen nacional y el nivel educativo parecen ser muy alto. También se supo que el nivel educativo y ocupación de los padres se correlaciona a sus expectativas específicas para el futuro educativo de sus hijos..

Palabras clave: capital cultural institucionalizado; objetivado capital cultural; expectativas educacionales; escuela primaria; nativos; inmigrantes 


\section{Koustourakis, Asimaki \& Spiliopoulou - Cultural Capital}

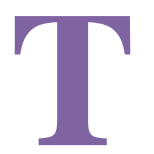

he social, political and economic changes which occurred from the 1990's onwards contributed to the gradual transformation of Greece from an immigrant-sending country to an immigrantreceiving country. Contemporary Greek society has become multicultural due to the influx of immigrants mainly from Balkan countries, as well as from African and Asian countries (Cavounidis, 2002; Kasimis \& Papadopoulos, 2005; Labrianidis \& Lyberaki, 2001; Labrianidis, Lyberaki, Tinios, \& Hatziprokopiou, 2004; Papanikolaou, 2009). The multicultural character of Greek society also reflects on the field of school, where children who come from different socio-cultural backgrounds study (Motti-Stefanidi, Asendorpf, \& Masten, 2012; Motti-Stefanidi, Pavlopoulos, Obradović, \& Masten, 2008).

From the study of scientific literature we conclude that the cases of families with an immigrant background and native families have been widely detected, a fact which can also be seen through the presentation of the following scientific papers in the form of thematic categorization: a) parents' involvement in the educational processes of schools which could be characterized as multicultural because of the composition of their student population (Levine-Rasky, 2009; Seyfried \& Chung, 2002; Turney \& Kao, 2009), b) the practices which immigrant parents adopt concerning the school achievement of their children (Bodovski, 2010; Toldson \& Lemmons, 2013), and c) the influence of the socio-economic status of the family on the educational expectations of parents for their children (Koo, 2012; Räty, 2006; Räty, Leinonen, \& Snellman, 2002). The present paper attempts to enhance scientific literature through the investigation of the correlation between the factors: nationality, forms of cultural capital (institutionalized and objectified) and educational expectations.

The purpose of this study is twofold, since it attempts to investigate the similarities and differences between institutionalized and objectified cultural capital of native and immigrant parents of $6^{\text {th }}$ grade state primary school students in the city of Patras, as well as to correlate these parents' expectations for the educational future of their children in accordance with these two forms of cultural capital.

The paper begins with the theoretical framework, there follow the research questions and the methodology, and next, the research findings are presented and analyzed. The study closes with the section containing the 
discussion and conclusions.

\section{Theoretical Framework}

Bourdieu (1977b, 1986, 1994) identifies three forms of cultural capital: the embodied, the objectified and the institutionalized in the form of educational credentials.

The embodied cultural capital, which is according to Pierre Bourdieu always directly linked to the body and presupposes a labor of inculcation, is defined as 'a system of durable, transposable dispositions, structured structures predisposed to function as structuring structures' which regulates the mental activity of social agents (Bourdieu, 1977b, p. 72; 1990, p. 53; Noble \& Watkins, 2003, pp. 521-522; O'Brien \& Ó Fathaigh, 2005, p. 68). It includes knowledge, skills and modes of thought which are embodied via an invisible hereditary transmission to individuals through continuous socialization processes. It constitutes 'a have that became a be', a personal capital, a property (Bourdieu, 1986; 1994, p. 78; Carrington \& Luke, 1997, p. 102; Devine, 2009, p. 522).

The cultural capital in its objectified state refers to cultural goods, such as paintings, works of art, books, bookcases, writings, musical and scientific instruments. It is transmissible in its materiality in comparison with the embodied cultural capital which 'declines and dies' according to the biological singularity of its bearer (Bourdieu, 1986; 1994, p. 81; Carrington \& Luke, 1997, p. 103; Devine, 2009, p. 522; Levitas, 2004, p. 51; O'Brien \& Ó Fathaigh, 2005, p. 69). However, the ability of the "conception" and approach of cultural goods depends on the embodied cultural capital the individual possesses; namely, it depends on individual habitus characteristics which are the result of the intersection between objectified social structures and socialization processes (Bourdieu, 1986; 1994, p. 81; Carrington \& Luke, 1997, p. 103).

The institutionalized cultural capital in the form of educational credentials (a form of objectification) refers to academic qualifications and credentials which are legalized by authorized social institutions, such as schools, universities and technological institutes (Bourdieu, 1986, p. 248; Carrington \& Luke, 1997, p. 103; Devine, 2009, p. 522; Levitas, 2004, p. 51; O'Brien \& Ó Fathaigh, 2005, p. 69). 


\section{Koustourakis, Asimaki \& Spiliopoulou -Cultural Capital}

The question, thus, which arises in the specific paper refers to the interrelation and differentiation of these two forms of cultural capital (institutionalized and objectified) with the educational expectations of native and immigrant parents for their children.

\section{Research Questions - Methodology}

In this paper, we are going to deal with the answer to the following research questions:

- What are the similarities and differences between the institutionalized and objectified cultural capital of native and immigrant parents of $6^{\text {th }}$ grade state primary school students in the city of Patras?

- How do these two forms of cultural capital belonging to the specific parents correlate with their expectations for the educational future of their children?

The research was conducted during the spring semester of 2014 with the use of semi-structured interviews, in which 20 parents (10 native and 10 immigrant), whose children were in the $6^{\text {th }}$ grade of state primary schools in the city of Patras, participated. Patras was chosen for the conduction of this research since it is the third largest city in Greece and a great number of immigrant families live here, mainly from Albania. These immigrant families resident in specific working-class areas of the city of Patras. It is noted that during the interviewing process both parents were present, while mothers mainly answered our questions. Fathers participated complementarily, in order to give more explanations or add some more elements when it was necessary.

As far as the nationality of the parents of the families who participated in the research is concerned, ten were of Greek origin and ten Albanian. All immigrants who participated in the research were Albanians since they constitute the largest group of immigrants in Greece and especially the vast majority of immigrants in Patras. In terms of place of residence, sixteen (six of Greek origin and all immigrant families) lived in working-class areas of the city of Patras and four Greek families lived in urban areas. Concerning 
the educational level of the parents of the families who participated in the research, according to their gender the following can be noted:

a) Five Greek mothers possessed 'strong' institutionalized cultural capital, because they had graduated from higher education (Technological Educational Institutes, Universities) and one of them held a Master's Degree. Moreover, four Greek mothers had graduated from lyceum and one had graduated from gymnasium. Concerning immigrant mothers, one had graduated from a Technological Educational Institute in Albania and had specialized in Electrology, six had graduated from lyceum and three had graduated from gymnasium.

b) In terms of the education of the Greek fathers, four had graduated from tertiary education, five from lyceum and one from primary school. In contrast, all immigrant fathers had graduated from lyceum.

In addition, concerning the distribution of occupation of the parents who participated in the research, according to their gender it is noted that:

a) As far as the Greek mothers are concerned, one was a Psychologist, two were Greek language teachers one was an English teacher, one was a Pharmacist, one was a decorator, one was a trade store employee and three were housewives. From the sum total of immigrant mothers only one was a housewife and the other nine were domestic workers.

b) The occupation of the Greek fathers is distributed as follows: one was an economist, one was an architect, one was a theologian-priest, one was a civil servant, two were tradesmen, one was a taxi-driver, two were technicians and one was unemployed. All immigrant fathers, as it occurs in almost all Albanians in Patras, were occupied in technical and working-class jobs. These occupations do not permit the economic and social upgrade of the immigrants' life.

A schedule of semi-structured interview questions was created for the purposes of the research. Specifically, this schedule consisted of a series of questions, statements or items and the respondents were asked to answer, respond to or comment on them in a way that they think best (Cohen, Manion, \& Morrison, 2007, p. 321). The interviews were either tape recorded, or the answers transcribed in detail, depending on the preference of the research subjects (Iosifides, 2003; Robson, 2007). Afterwards, the technique of content analysis of the research data that emerged either from the tape-recording of the interviews or from the detailed transcriptions of the 


\section{Koustourakis, Asimaki \& Spiliopoulou -Cultural Capital}

research participants was used (Iosifides, 2008; Psarrou \& Zafeiropoulos, 2004). 'Sentences' are taken as the units of analysis which are not understood according to their grammatical sense but according to their semantic meaning (Koustourakis, 2014; Koustourakis \& Zacharos, 2011; Neves \& Morais, 2001). The sentences were placed into one of the following categories of analysis that emerged from the objective and the theoretical framework of the specific research:

A. Objectified cultural capital of native and immigrant families

B. Cultural activities of native and immigrant families

B.1. Reading extracurricular books

B.2. Exposure to music and musical preferences

B.3. Discussion topics in the family context

B.4. Engagement of the families' children in extracurricular activities

C. Educational expectations of parents for their children

D. Occupational expectations of parents for their children

E. Dreams and expectations of parents for the future of their children

In the following section the research results are presented and analyzed.

\section{Presentation and Analysis of the Results}

The presentation of the research findings, which refers to the qualitative analysis of the research material that emerged from the decoding of the data from the semi-structured interviews with Greek and immigrant parents of $6^{\text {th }}$ grade primary school students in the city of Patras, takes place in accordance with the categories of analysis outlined above.

\section{A. Objectified Cultural Capital of Native and Immigrant Families}

The research findings showed that the majority of parents (natives and immigrants) possess cultural goods in their house, which, however, are differentiated according to their national origin and their educational and occupational level.

More specifically, native parents with a high educational and occupational level possessed 'strong' objectified cultural capital, since there 
were works of art in their houses (such as paintings of the saints and copies of the paintings of well-known and lesser-known artists), a great number of bookcases with various kinds of books (literature books, school textbooks, school aids, university textbooks, documents, encyclopedias, dictionaries and foreign books), as well as different kinds of musical instruments (such as guitar, piano, bass, percussion and flute). The following extract from an interview with a parent with a high educational and occupational level is indicative:

There are copies of works of art. Also, there are original paintings of the saints... We have three bookcases for our own books and for the children... There are the priest's church books, university textbooks, Greek, Latin, English-Greek and French-Greek dictionaries, books with research content, many literature books, as well as school textbooks (Interview 10 - I.10).

A differentiation concerning the cultural goods which existed in the houses of Greek families where the parents weren't university graduates in comparison with Greek families who had a high educational and occupational level is noted. The following comment made by a Greek mother with only compulsory education is characteristic:

There aren't any works of art in the house... We have a bookcase with encyclopedias, school textbooks, Greek and foreign dictionaries, English books and literature books... We have a flute, our daughter is being taught flute in the Music lesson at school (I.2).

The research data showed that the majority of parents with an immigrant background had few cultural goods in the house. The following statements of immigrant parents are representative:

No, we haven't got any bookcases. We have only one table on which our children put their books... There are school textbooks and a few fairytales borrowed from their school... There are no literature books... No, there isn't any musical instrument (I.7).

We don't have any bookcase, books are put on shelves in our bedrooms... There are my daughter's school textbooks, encyclopedias, 


\section{Koustourakis, Asimaki \& Spiliopoulou -Cultural Capital}

dictionaries, English books, fairytales, literature books... No, there isn't any musical instrument in our house (I.12).

In addition, all Greek parents with a high educational and occupational level have understood the significance of the existence of cultural goods in their house, which are interrelated with the 'objectified' form of cultural capital. Thus, the following comment made by a Greek mother who belongs to this category is characteristic, as she notes that:

We have works of art... mainly copies... Let's say that we have some paintings by Picasso, and some other copies... and some handmade works of art by lesser known artists... but they are still worth looking at (I.1).

Besides, Greek parents of socio-culturally privileged families seem to possess the permanent and durable predispositions needed to approach a cultural good effectively (Bourdieu, 1979; Lamnias, 2001, p. 158).

\section{B. Cultural Activities of Native and Immigrant Families}

As far as the cultural activities of family members at home are concerned, mainly differences emerge, according to their educational and occupational level as well as the national origin of the parents.

\section{B.1. Reading extracurricular books}

Greek parents with a high educational and occupational level claimed that they are fond of reading extracurricular books. This practice also seems to be adopted by their children 'internalizing' the cultural capital of their family. Such a fact reveals that the specific children acculturate the basic elements of their legitimate family culture (Bourdieu, 1979; Levitas, 2004, p. 51). In this case, as is also evident from the following interview extract, Greek children who come from socio-culturally privileged families seem to 'internalize' a primary habitus which stems from their previous experiences in the field of the family (Bourdieu \& Passeron, 1970; Jacobs, 2007, p. 250).

We are fond of reading extracurricular books. We read different 
writers' books, such as Papadiamantis, the Complete Works of Kazantzakis... We love reading poetry as well, such as the poems of Palamas, Ritsos and Kavafis... Our children read extracurricular books... Our daughter reads classical literature (I.10).

Reading extracurricular books doesn't constitute a practical choice of the Greek parents who participated in the research and who had a middle or low educational level. Therefore, a Greek mother who had completed only compulsory schooling states characteristically:

No, we don't read extracurricular books... Our daughter sometimes reads. She borrows them from school. There is a lending library... For example, she has read 'Irene', 'Hippies', 'Chickens' (Ornithes), as well as 'Frogs' (Vatrachoi) by Aristophanes (I.2).

In this case, it seems that some students, through the pedagogic effort of the school, acquire a set of predispositions (a secondary habitus) which is incorporated into their manner of perception and action (Mills, 2008, p. 80) and is different from that of their parents. Besides, according to Bourdieu (2002, p. 29): 'Dispositions are long-lasting: they tend to perpetuate, to reproduce themselves, but they are not eternal... Any dimension of habitus is very difficult to change but it may be changed through the process of awareness and pedagogic effort'.

Thus, the habitus which the daughter of the specific mother possesses, while it has been produced through family upbringing (structured structure) continues to be produced through the influence of experiences acquired at school (structuring structure) (Bourdieu, 1990; Maton, 2008) and in that way it gradually differs from her parents' habitus.

Besides, the majority of immigrant parents don't read extracurricular books and the same is true of their children. However, two cases of immigrant mothers who read extracurricular books are noted, and the same practice is adopted by their children, as emerges from the following extract as well:

Yes, I read literature books... Dostoyevsky and Tolstoy. I borrow these books from the ladies whose houses I clean. In Albania I used to visit the library and read Albanian poems... I really love poetry... My 


\section{Koustourakis, Asimaki \& Spiliopoulou -Cultural Capital}

daughter reads extracurricular books... The 'Little Prince', the 'High Mountains' (I.20).

Consequently, the children of immigrant parents who participated in the research seem to accumulate their parents' habits through a set of successive socializations and they imprint them on practices. So, family habitus structures the 'repertoire' of behaviour of young family members (Bourdieu \& Passeron, 1970; Thompson, 2009, p. 37).

\section{B.2. Exposure to music and musical preferences}

The research results reveal mainly differences concerning the musical preferences of our research subjects. Native parents with a high educational and occupational level prefer listening to different kinds of music, such as rock, art music, jazz and classical music, and these preferences are, in most cases, adopted by their children. Listening to classical music, which constitutes, among other, things an element of cultural capital, seems to be mainly adopted by socio-culturally privileged families (Bourdieu, 1979). Such a fact is noted in the following interview extract:

We mostly love listening to classical music... Beethoven, Mozart, Tchaikovsky... We also listen to Chatzidakis, Theodorakis. However, we love listening to art music as well... Our children listen to the same kinds of music as us. In fact, while reading, they sometimes love listening to classical music at a low volume, such as 'Swan Lake' (I.9).

However, the musical choices of native parents who have completed only compulsory and lyceum education seem to be different in comparison with those of their children. More specifically, some parents mainly prefer listening to folk and popular idiom of music, whereas their children are fond of listening to pop and rock music. In this case, children seem to be adapted to the interests of their peer groups, with whom they are in touch, and who constitute a fundamental socializing factor (Hughes \& Kroehler, 2009). Thus, a mother with lyceum education states characteristically: We mainly listen to folk music... Our children listen to more modern music than us. Pop, rock... or classical music, such as Beethoven's 'Ninth Symphony' and Vivaldi's 
'Four Seasons' ... as well as 'Swan Lake' (I.4).

In addition, a Greek mother with lyceum level education states that she herself, her husband, as well as her children mainly listen to electronic art music and classical music. Such a fact reveals the influence of parents on the musical preferences of their children: We listen to classical and electronic art music. And our children do too (I.3).

Most immigrant parents stated that they mainly prefer listening to folk music, while: Our children listen to folk music like us and pop music as well (I.18).

According to the above extracts we conclude that musical preferences are differentiated between families. Thus, the different social and cultural background of the social subjects who participated in the research is illustrated in their different musical choices and preferences (Moore, 2008, pp. 106-107).

\section{B.3. Discussion topics in the family context}

The analysis of the interview data revealed that there are mainly similarities concerning the discussion topics developed between family members. In fact, discussions between children - parents regardless of the national origin and educational and occupational background of parents focus mainly on issues which concern the children's school and study/homework. Furthermore, family members are used to discussing daily problems, sports, as well as social, occupational and economic issues and problems, which interested them, with each other.

Thus, a Greek mother with a high educational and occupational level mentions: We talk about the children's school, about various social issues depending on the age of the children (I.10).

Also, another Greek mother with a low educational and occupational level states:

We discuss the children's school, how they spent their day, their school subjects, their progress... politics and how it impacts on our life... reference is made to that issue as well. Besides, we hear it all the time on TV. We also discuss various everyday life issues which interest us (I.4). 


\section{Koustourakis, Asimaki \& Spiliopoulou -Cultural Capital}

In addition, an immigrant mother with a high educational level states, concerning the discussion topics in the context of her family: We mainly discuss school... we also discuss their study/homework... the crisis, politics, our jobs (I.16).

\section{B.4. Engagement of the families' children in extracurricular activities}

The research findings show that parents (natives and immigrants) emphasize the accumulation of cultural capital in their children through their engagement in activities, such as sports, dancing, painting and the learning of foreign languages. Moreover, they also expect their children to be engaged in more extracurricular activities before they complete primary school.

Thus, a Greek mother with a high educational and occupational level states in a characteristic way:

I really would like my daughter to keep on learning a musical instrument... And I really would like her to learn another foreign language... That would help her a lot because if she doesn't speak two foreign languages I can't imagine what she will be able to do in her life. Because things are getting really hard (I.8).

Also, another Greek mother with a low educational and occupational level notes: I would like him to keep on learning English, learn another foreign language, such as French... keep on learning sports... and complete the guitar lessons he is already engaged in (I.3).

Moreover, an immigrant mother with a low educational and occupational level mentions: I would like my daughter to learn English, guitar and painting because she really likes them, as well as to keep on learning traditional dances (I.17).

Consequently, from the statements of the sample of families concerning cultural goods which exist in their house, and the cultural activities they are engaged in during their spare time, we conclude that there is a strong 'accumulation' of cultural capital in the houses mainly of socio-culturally privileged families. That entails the enhancement of 'accumulation' of the embodied form of cultural capital in their children who are raised in such 
environments. These children acquire various cultural stimuli which are internalized into their manner of thought and action (Bourdieu, 1977a, 1979).

\section{Educational expectations of parents for their children}

The findings of the research reveal that all parents regardless of national origin, educational and occupational level have very high expectations for the educational future of their children. In particular, parents expect their children to complete lyceum and afterwards to study at University and if the children themselves want to, to pursue postgraduate and $\mathrm{PhD}$ studies. This finding agrees with other research findings according to which parents regardless of national origin and educational and occupational level expect their children to pursue university studies (Devine, 2009; Kirk, Lewis-Moss, Nilsen, \& Colvin, 2011; Koo, 2012).

Thus, a Greek mother with a high educational and occupational level states, regarding her expectations for the educational future of her daughter: I would like her to complete lyceum and after that if she wants to herself, to study at University (I.9).

Adopting the same point of view another Greek mother with a low educational and occupational level mentions: I would like her to complete gymnasium, lyceum and if she is capable of it... to study at University afterwards... It would be ideal if she pursued postgraduate studies or $\mathrm{PhD}$ studies (I.5).

Also, an immigrant mother with a low educational and occupational level notes characteristically: I would definitely like her to complete lyceum and study at University afterwards... if she was capable of pursuing postgraduate studies it would be the best for her future (I.15).

\section{Occupational expectations of parents for their children}

All parents regardless of national origin, educational and occupation level seem to have high occupational expectations for the future of their children. In particular, parents who wanted their children to pursue higher scientific occupations (such as: Lawyer and Political Engineer), medical occupations (such as: Doctor and Dentist), educational occupations (such as: Teacher and 


\section{Koustourakis, Asimaki \& Spiliopoulou - Cultural Capital}

Nursery Teacher) and occupations relevant to the army and the security corps (such as: Police officer and Fireman). The last case draws the attention mainly of parents from socio-culturally underprivileged families, because occupations associated with the armed forces and the police ensure immediate job stability in Greece, and students receive a bonus from the $1^{\text {st }}$ year of their studies (Bourdieu, 1979; Bourdieu \& Passeron, 1970).

Thus, a Greek mother of a low educational and occupational level notes:

I would like my daughter to become a Police officer. My daughter wants the same as well... It suits her character because she is dynamic. It is a job which could offer her money in order for her to live, and it also means she will be able to find a job more easily in comparison with other jobs' (I.2).

Another Greek woman with a high educational and occupational level mentions, regarding her daughter:

I think that it would suit her to become a Nursery Teacher. She is good with small children and as I see she has an inclination towards theoretical school subjects... The same thing has been expressed by her... She would like to become a Nursery Teacher (I.10).

Furthermore, an immigrant mother with a low educational and occupational level states: I would like my daughter to become a Lawyer. She is fond of reading, she is dynamic and she is doing well in Greek Literature in History (I.14).

\section{E. Dreams and expectations of parents for the future of their children}

As far as the general dreams, expectations and aspirations of parents regarding the future of their children are concerned, all those who participated in the research state that above all they want their children to be healthy, to be correct citizens in society, as well as to have values and ideals. Also, they draw attention to their children's character and personality because they believe that these are decisive for the educational and occupational future of their children.

In particular, a Greek mother with a high educational and occupational 
level states about her dreams concerning the future of her child:

To be healthy, have values and ideals, acquire a multifaceted education and choose a job that will make her happy, as well as enable her to offer something to her fellow beings (I.9).

Moreover, immigrant parents expect their children to have a better and better quality life in Greece in comparison with their life. And that could be achieved through a differentiated educational and occupational future from that of their parents: To be healthy, be educated and find a stable job in order to live... so as to have a good life in the future (I.13).

To be a good person, be strong and have a stable job even if he doesn't earn a lot of money... this is basic because things are really hard nowadays... And to be educated because it is difficult for someone to find a job without education (I.18).

The research findings revealed that parents expect their children to make educational, occupational and social progress. In fact, the opinions of immigrant parents regarding the educational and occupational course of their children seem to have been determined by their own usually negative personal life experiences in the country of origin. More specifically, an immigrant mother refers in a characteristic way to the difficult life circumstances in Albania and her wish to make a fresh start in Greece, which constitutes the host country:

We have been in Greece since my daughter was five years old. It was difficult for us to stay in Albania... We thought that it would be better to start our life from the beginning in Greece and for the education of our child (I.12).

Also, another immigrant mother adds:

Yes, it was difficult. That's why we left. However, it is now difficult in Greece as well. But we don't want to return because if our children attend another school they won't be able to go through with it in Albania (I.17). 


\section{Koustourakis, Asimaki \& Spiliopoulou - Cultural Capital}

The specific immigrant parents recognize the difficulty which exists in Greek society nowadays because of the economic crisis. That's why they consider that education is the most important 'investment' for the future of their children (Devine, 2009). In fact, it seems that the negative experiences immigrant parents have had in the work and the social field urged them to desire the social improvement of their children by using the opportunities the educational field offers. And that comes about so that their children will escape from their own socio-economic circumstance which is negatively evaluated by them and which they experience as a cultural devaluation (Lehmann, 2009, pp. 146-147).

\section{Discussion and Conclusions}

The 'objectified' cultural capital of native and immigrant families, which is manifest in works of art, bookcases, kinds of books which exist in a bookcase as well as in the existence of musical instruments at home, seem to vary between research subjects. In particular, it is concluded that native parents with a high educational and occupational level possess a stronger 'objectified' cultural capital in their house in comparison with native and immigrant parents of a low educational and occupational level. In this case, children from socio-culturally privileged families are getting familiar with various cultural goods enhancing in that way their 'embodied' and 'objectified' cultural capital (Bourdieu, 1977a, 1979; Bourdieu \& Passeron, 1970).

Cultural activities of family members at home, which refer to reading extracurricular books, kinds of music, as well as discussion topics developed between them, seem, also, to be differentiated according to educational and occupational level as well as national origin of parents. More specifically, reading extracurricular books is mainly adopted by native parents with a high educational and occupational level, something which seems to be acculturated by their children as well (Bourdieu, 1979, 1986; Bourdieu \& Passeron, 1970). From the statements of the interviewed parents we conclude that some children acculturate from their family the habit of reading extracurricular books and, as a consequence, they acquire 'a system of lasting, transposable dispositions which functions as a matrix of perceptions, appreciations and actions' (Bourdieu, 1977b, p. 83; Sianou- 
Kyrgiou \& Tsiplakides, 2009, p. 729). The field of the family structures the habitus of its holders and that, in turn, contributes to the meaning of the family field (Maton, 2008).

From the research the role of the school in the completion of the limited cultural stimuli to children from socio-culturally disadvantaged environments was clear, and it restructures, possibly, in that way the primary manner of their perception and action, because it gives them the opportunity to read extracurricular books through the school lending library. The above mean that onto primary habitus secondary habitus are 'transplanted' and specifically school habitus (Accardo, 1991).

The kind of music family members prefer listening to varies. Children, in most cases, seem to incorporate the musical choices of their parents imprinting them on action. The collective habitus of the family is internalized into the individual habitus of children, as social subjects are products of similar social conditions (Koca, Atencio, \& Demirhan, 2009, p. 57). The acquisition of a great volume of cultural capital seems to play a role in the musical preferences of parents. The more 'enhanced' the cultural capital of the family is, the more 'cultivated' are its musical choices. That is evident in their listening to classical music, which seems to be mainly adopted by culturally privileged families.

In addition, the fact that the topics of discussion between parents and children focus mainly on school issues, reading and the children's preparation for the next day's school lessons, as well as on current social issues and problems derived from their daily life is characteristic.

Besides, all parents, regardless of national origin, educational and occupational level have very high expectations for the educational and occupational future of their children. Furthermore, it is concluded that parents (natives and immigrants) draw attention to the 'accumulation' of cultural capital in their children through their present and future engagement in extracurricular activities, such as foreign languages, music, sport, dancing and painting.

Our research findings agree with the research findings of Stevenson \& Willott (2007) according to which many immigrant parents have high educational expectations for their children, as they see higher education as a route out of poverty and social discrimination, as well as a key means of social integration. Also, the findings of this research are in keeping with 


\section{Koustourakis, Asimaki \& Spiliopoulou - Cultural Capital}

those of the study of Li (2004) from which it emerges that immigrant parents expect their children to be well educated so as to have a better quality of life in comparison with their parents' life and ensure a good professional future.

To sum up, from the present research paper the following conclusions emerge:

- There are more differences than similarities between native and immigrant parents and they focus on cultural goods which exist in their houses, as well as on the cultural activities of family members during their spare time.

- Native students who come from socio-culturally advantaged environments seem to accumulate a greater volume of 'embodied' and 'objectified' cultural capital from their family environment in comparison with native students and students with an immigrant background who come from socio-culturally disadvantaged environments.

- Educational expectations of the students' parents regardless of national origin and educational background, seem to be very high for their children. Specifically, all parents, natives and immigrants, wanted their children to complete lyceum and pursue university studies afterwards.

- Educational level and occupation of the students' parents seem, also, to be correlated with their expectations for the educational future of their children. Particularly, socio-culturally advantaged native families expected their children to pursue either higher scientific occupations or medical occupations with high prestige, such as doctor and dentist. Socio-culturally disadvantaged Greek families, as well as immigrant families, wanted their children to choose occupations which are, mainly, associated with the armed forces and the police. And that comes about because they thought that these occupations ensure immediate job stability. At this point we should mention that either Albanian families, who participated in the research, had acquired Greek citizenship or they had tried to ensure it and they wanted their boys to join the Greek army.

Although the findings of this qualitative research are not generalized they are interesting because they reveal the similarities and differences in the forms of cultural capital which exist between native and immigrant parents, as well as their correlation with their dreams and expectations for the 
educational future of their children. The carrying out of similar research on a larger scale in Greece or in other host countries for immigrants in Europe, such as Italy and Spain, would be interesting.

\section{References}

Accardo, A. (1991). Initiation à la Sociology. L'illustrationnisme social. Bordeaux: Le Mascaret.

Bodovski, K. (2010). Parental practices and educational achievement:

social class, race, and habitus. British Journal of Sociology of

Education, 31(2), 139-156. doi:10.1080/01425690903539024

Bourdieu, P. (1977a). Cultural reproduction and social reproduction. In J.

Karabel \& A. H. Halsey (Eds.), Power and ideology in education

(pp. 487-511). New York: Oxford University Press.

Bourdieu, P. (1977b). Outline of a theory of practice. London: Cambridge University Press.

Bourdieu, P. (1979). La distinction: Critique sociale du jugement. Paris:

Les Éditions de Minuit.

Bourdieu, P. (1986). The forms of capital. In J. Richardson (Ed.),

Handbook of theory and research for the sociology of education (pp.

241-258). New York: Greenwood Press.

Bourdieu, P. (1990). The logic of practice. Cambridge: Polity Press.

Bourdieu, P. (1994). Texts of Sociology. Athens: Delfini.

Bourdieu, P. (2002). Habitus. In J. Hillier \& E. Rooksby (Eds.), Habitus: A sense of place (pp. 27-37). Aldershot: Ashgate.

Bourdieu, P., \& Passeron, J.-C. (1970). La reproduction. Éléments pour une théorie du système d'enseignement. Paris: Les Éditions de Minuit.

Carrington, V., \& Luke, A. (1997). Literacy and Bourdieu's sociological theory: A reframing. Language and Education, 11(2), 96-112.

Cavounidis, J. (2002). Migration in Southern Europe and the case of

Greece. International Migration, 40(1), 45-70. doi: /10.1111/14682435.00185/pdf

Cohen, L., Manion, L., \& Morrison, K. (2007). Research methods in education. London and New York: Routledge. 
Devine, D. (2009). Mobilizing capitals? Migrant children's negotiation of their everyday lives in school. British Journal of Sociology of Education, 30(5), 521-535. doi:10.1080/01425690903101023

Hughes, M., \& Kroehler, C. J. (2009). Sociology the core. Boston: McGraw Hill.

Iosifides, T. (2003). Analysis of qualitative data in social sciences. Athens: Kritiki.

Iosifides, T. (2008). Qualitative methods of research in social sciences. Athens: Kritiki.

Jacobs, A. (2007). Examinations as cultural capital for the Victorian school girl: 'thinking' with Bourdieu. Women's History Review, 16(2), 245261. doi:10.1080/1369183042000305708

Kasimis, C., \& Papadopoulos, A. G. (2005). The multifunctional role of migrants in the Greek countryside: Implications for the rural economy and society. Journal of Ethnic and Migration Studies, 31(1), 99-127. doi:10.1080/1369183042000305708

Kirk, C. M., Lewis-Moss, R. K., Nilsen, C., \& Colvin, D. Q. (2011). The role of parent expectations on adolescent educational aspirations. Educational Studies, 37(1), 89-99. doi:10.1080/03055691003728965

Koca, C., Atencio, M., \& Demirhan, G. (2009). The place and meaning of the field of PE in Turkish young people's lives: a study using Bourdieu's conceptual tools. Sport, Education and Society, 14(1), 5575. doi:10.1080/13573320802615130

Koo, A. (2012). Is there any chance to get ahead? Education aspirations and expectations of migrant families in China. British Journal of Sociology of Education, 33(4), 547-564. doi:10.1080/01425692.2012.678755

Koustourakis, G. (2014). A sociological approach to painting teaching according to the contemporary Greek kindergarten curriculum. The International Journal of the Early Childhood Learning, 20(1), 23-37. Koustourakis, G., \& Zacharos, K. (2011). Changes in School Mathematics Knowledge in Greece: a Bernsteinian Analysis. British Journal of Sociology of Education, 32(3), 369-387. doi:10.1080/01425692.2011.559339 
Labrianidis, L., \& Lyberaki, A. (2001). Albanian immigrants in

Thessaloniki: paths of prosperity and oversights of their public

image. Thessaloniki: Paratiritis.

Labrianidis, L., Lyberaki, A., Tinios, P., \& Hatziprokopiou, P. (2004).

Inflow of migrants and outflow of investment: Aspects of

interdependence between Greece and the Balkans. Journal of Ethnic

and Migration Studies, 30(6), 1183-1208.

doi:10.1080/1369183042000286304

Lamnias, K. (2001). Sociological theory and education. Athens:

Metaixmio.

Lehmann, W. (2009). University as vocational education: working-class students' expectations for university. British Journal of Sociology of Education, 30(2), 137-149. doi:10.1080/01425690802700164

Levine-Rasky, C. (2009). Dynamics of parent involvement at a multicultural school. British Journal of Sociology of Education, 30(3), 331-344. doi:10.1080/01425690902812604

Levitas, R. (2004). Let's hear it for Humpty: social exclusion, the third way and cultural capital. Cultural Trends, 13(2), 41-56.

doi:10.1080/0954896042000267143

Li, J. (2004). Parental expectations of Chinese immigrants: a folk theory about children's school achievement. Race Ethnicity and Education, 7(2), 167-183. doi:10.1080/1361332042000234286

Maton, K. (2008). Habitus. In M. Grenfell (Ed.), Pierre Bourdieu: Key Concepts (pp. 49-65). Stocksfield: Acumen.

Mills, C. (2008). Reproduction and transformation of inequalities in schooling: the transformative potential of the theoretical constructs of Bourdieu. British Journal of Sociology of Education, 29(1), 79-89. doi:10.1080/01425690701737481

Moore, R. (2008). Capital. In M. Grenfell (Ed.), Pierre Bourdieu: Key Concepts (pp. 101-117). Stocksfield: Acumen.

Motti-Stefanidi, F., Asendorpf, J. B., \& Masten, A. S. (2012). The adaptation and well-being of adolescent immigrants in Greek schools: A multilevel, longitudinal study of risks and resources. Development and Psychopathology, 24, 451-473.

Motti-Stefanidi, F., Pavlopoulos, V., Obradović, J., \& Masten, A. S. (2008). Acculturation and adaptation of immigrant adolescents in Greek 
urban schools. International Journal of Psychology, 43(1), 45-58. doi: 10.1080/00207590701804412

Neves, I., \& Morais, A. (2001). Texts and contexts in educational systems: Studies of recontextualising spaces. In A. Morais, I. Neves, B. Davies \& H. Daniels (Eds.), Towards a Sociology of Pedagogy. The Contribution of Basil Bernstein to Research (pp. 223-249). N.Y.: Peter Lang.

Noble, G., \& Watkins, M. (2003). So, how did Bourdieu learn to play tennis? Habitus, consciousness and habituation. Cultural Studies, 17(3-4), 520-539.

O'Brien, S., \& Ó Fathaigh, M. (2005). Bringing in Bourdieu's theory of social capital: renewing learning partnership approaches to social inclusion. Irish Educational Studies, 24(1), 65-76. doi:10.1080/03323310500184509

Papanikolaou, D. (2009). Repatriation on screen: National culture and the immigrant other since the 1990s. In D. Tziovas (Ed.), Greek Diaspora and Migration since 1700 (pp. 255-270). Aldershot: Ashgate.

Psarrou M. K., \& Zafeiropoulos, K. (2004). Scientific research. Theory and applications in Social Sciences. Athens: Typothito - G. Dardanos.

Räty, H. (2006). What comes after compulsory education? A follow-up study on parental expectations of their child's future education. Educational Studies, 32(1), 1-16. doi:10.1080/03055690500415837

Räty, H., Leinonen, T., \& Snellman, L. (2002). Parents' educational expectations and their social-psychological patterning. Scandinavian Journal of Educational Research, 46(2), 129-144. http://dx.doi.org/10.1080/00313830220142164

Robson, C. (2007). Real world research. A resource for social scientists and practitioner researchers. Athens: Gutenberg.

Seyfried, S. F., \& Chung, I.-J. (2002). Parent involvement as parental monitoring of student motivation and parent expectations predicting later achievement among African American and European American middle school age students. Journal of Ethnic and Cultural Diversity in Social Work, 11(1-2), 109-131. doi:10.1300/J051v11n01_05 
Sianou-Kyrgiou, E., \& Tsiplakides, I. (2009). Choice and social class of medical school students in Greece. British Journal of Sociology of Education, 30(6), 727-740. doi:10.1080/01425690903235276

Stevenson, J., \& Willott, J. (2007). The aspiration and access to higher education of teenage refugees in the UK. Compare: A Journal of Comparative and International Education, 37(5), 671-687. doi:10.1080/03057920701582624

Thompson, R. (2009). Social class and participation in further education: evidence from the Youth Cohort Study of England and Wales. British Journal of Sociology of Education, 30(1), 29-42.

Toldson, I. A., \& Lemmons, B. P. (2013). Social demographics, the school environment, and parenting practices associated with parents' participation in schools and academic success among Black, Hispanic, and White students. Journal of Human Behavior in the Social Environment, 23(2), 237-255.

Turney, K., \& Kao, G. (2009). Barriers to school involvement: Are immigrant parents disadvantaged? The Journal of Educational Research, 102(4), 257-271. doi:10.3200/JOER.102.4.257-271

Dr. Gerasimos Koustourakis is Associate Professor in Sociology of Education and School Knowledge at Department of Educational Sciences and Early Childhood Education in the University of Patras, Greece.

Dr. Anna Asimaki is an Assistant Professor in Sociology of Education at the Department of Primary Education of the University of Patras, Greece.

Georgia Spiliopoulou is Kindergarten Teacher, M.Ed. and Ph.D student in the Department of Educational Sciences and Early Childhood Education of the University of Patras, Greece.

Contact Address: koustourakis@upatras.gr 